the non-affected. But is there any evidence that the bearers of the diseases in question are abnormally susceptible to infectious disease? If this were so to any significant degree, it would certainly be apparent, even without such infections as cholera and smallpox, in a high death rate, and it is unlikely that the proportion of affected persons in the general population would be increasing, as is claimed.

The second point is the clearly stated attitude to inherited but curable disease. "It is as much against philanthropic ideals as against sound sense to cure the results of a bad constitution" if reproduction is allowed. Assuming that this book represents a certain class of opinion, there appears here to be serious ground for debate. Apart from the probability that the same or other defects would arise de novo, it seems reasonable to think that the problem of such diseases must be decided in human society, which is not merely a herd, on considerations other than that of the disease itself. In the evident absence of ideal individuals who can be guaranteed to breed ideal progeny indefinitely, there is as much to be said, on the present evidence, for using the triumphs of medical research to preserve the germ plasm we have, as for using them as an excuse for its destruction.

\section{The Eternal Village}

Hooton Pagnell: the Agricultural Evolution of a Yorkshire Village. By Dr. Arthur G. Ruston and Denis Witney. Pp. viii $+459+12$ plates. (London: Edward Arnold and Co., 1934.) $25 s$. net.

A SURPRISING number of English towns and A villages bear Saxon names, and it is remarkable how little the expanding population of the eighteenth and nineteenth centuries affected the number of settlements: old villages grew into towns, and adjacent villages gradually touched each other and became large cities, but there were not the new settlements that one sees in America. This persistence of the English village is one of its characteristic features, and in recent years there have been numbers of historical studies tracing particular villages back to their earliest times.

The village dealt with in the present volume, Hooton Pagnell in Yorkshire, has a special interest to the agriculturist because it was the residence in the early part of the fourteenth century of Sir Geoffrey Loutrell, who arranged for the making of the wonderful Psalter that bears his name and that gives us better pictures of agricultural operations than any other document of its time. The implements are so well shown that they could be reconstructed by a village smith without difficulty ; the men and animals are drawn with rare skill and vigour, and are obviously taken from life. Dr. Ruston and Mr. Witney have followed the history of the village from Domesday Book, where it is called "Hotone", right up to the present time, searching every old document they could find with the painstaking conscientious labour associated with all Dr. Ruston's work. Even apart from its intrinsic interest, the book is useful as showing the range and extent of sources of information about the village life of the past ; while the long quotations from the various documents serve to show the kind of use to which they may be put.

There have been no revolutions and no wars to speak of in the British countryside, and consequently the old records stored in church and manor house still survive in many places, furnishing material of considerable interest to present-day economists, geographers and agriculturists. In the English countryside, more perhaps than anywhere else in the world, the key to the present lies in the past: the things we now see have their roots deep down in the village history, and no one can understand the present position without a knowledge of how it came about. If, as sometimes happens with would-be social reformers, the story is quite unknown, or worse still, if it has been warped and twisted to suit a political theory, the vision will be wrong and the suggested reform is foredoomed to failure; only if the story is apprehended without prejudice and with a single eye to truth can any good emerge.

This book should be studied by all students of agricultural history, whether their interest be technical or social. It is well illustrated with maps showing the enclosures and the changes at the various times which have finally resulted in the village as it now stands. After perusing this book, the student will understand how it comes about that problems of tithe, of tenure and of tenant right, are so complex. E. J. RusselL.

\section{An Unorthodox Chemistry}

An Introduction to Chemistry. By Prof. Frank B. Kenrick. Pp. viii +434. (Toronto : University of Toronto Press, 1933.) 3 dollars.

DROF. KENRICK disarms criticism of this remarkable book by his statement in the preface that it "will not be found to be a 'teachable' book", but immediately throws down the gauntlet by continuing: "a teachable book must be a learnable book, and that is a most dangerous educational weapon". Such provocation in the preface whets our curiosity as to the text, but before we reach the latter we are 'brought up short' again by the table of contents. Chap. i begins with the manufacture of salt, and, after a 